\title{
ANTIMICROBIAL PRESCRIBING PATTERNS IN A GROUP OF PRIVATE PRIMARY HEALTH CARE CLINICS IN SOUTH AFRICA
}

\section{Norah L Katende-Kyenda}

M Pharm Sc, HDE (Cum Laude), M Pharm

Lecturer, Department of Pharmacology, Faculty of Health Sciences, Walter Sisulu University (Mthatha Campus), Mthata

Corresponding author: kyendanorah@yahoo.com

\section{Martie S Lubbe}

Ph D

Associate Professor and Head of Pharmacy Practice, School of Pharmacy, North-West University (Potchefstroom Campus), Potchefstroom

\section{Jan HP Serfontein}

D Pharm

Associate Professor and Head of Pharmaceutical Solutions \& Research Group, School of Pharmacy, North-West University (Potchefstroom Campus), Potchefstroom

\section{Ilse Truter \\ D Com, Ph D Pharm \\ Associate Professor and Head of Pharmacy Practice, Department of Pharmacy, Nelson Mandela Metropolitan University, Port Elizabeth}

Keywords: antimicrobials; South African private health sector; primary health care; rational drug therapy; drug utilisation

\begin{abstract}
The aim of this study was to investigate the prescribing of antimicrobials in private primary health care in South Africa. A retrospective drug utilisation study was conducted on data obtained from the database of nine private primary health care clinics for the year 2001. Antimicrobials were classified pharmacologically and their usage analysed according to number of patients and consultations, age groups, gender, diagnoses and cost. Of the 83655 patients, 49772 (59.50\%) were female and 33650 (40.22\%) males. No gender was indicated in 233 (0.28\%) of the cases. Medicine items ( $n=515976)$ were prescribed costing R1 716319 . Of these, $18.69 \%(n=96421)$ were antimicrobials costing R1 045108 (60.89\%). Antimicrobials were prescribed in 72\% of the consultations. The antimicrobials that were the most often prescribed were penicillins (38.17\%), sulphonamides (22.49\%), antiprotozoals (9.88\%) and tetracyclines (9.34\%) for diagnoses such as viral-influenza, upper-respiratory infections, acute-bronchitis and acute-sinusitis. Antibiotics prescribed for viral diseases indicated inappropriate use because these infections are caused by non-bacterial agents, and thus are self-limiting. Therefore antibiotics were neither necessary nor appropriate. Further investigations should be done on standard antimicrobial treatment-guidelines in private primary health care settings in South Africa.
\end{abstract}

\section{OPSOMMING}

Die doel met hierdie studie was om die voorskryfpatrone van antimikrobiese middels in private primêre gesondheidsorginrigtings in Suid-Afrika te ondersoek. ' $n$ Retrospektiewe medisyneverbruikstudie is uitgevoer op data wat verkry is vanaf die databasis van nege private primêre gesondheidsorgklinieke vir die jaar 2001. Antimikrobiese middels is farmakologies geklassifiseer en 'n analise van die verbruik is volgens die aantal pasiënte en konsultasies, 
die ouderdomsgroep, geslag, diagnose en koste gedoen. Van die 83655 pasiënte was 49772 (59.50\%) vroulik en 33650 (40.22\%) manlik. In 233 (0.28\%) van die gevalle is geen geslag aangedui nie. Die koste van voorgeskrewe mediese items ( $n=96421$ ) het R1 716319 (60.89\%) beloop. Antimikrobiese voorskrifte het 18.69\% ( $n=96416)$ van die total aantal voorskrifte uitgemaak teen 'n koste van R1 045108 (60.89\%). Antimikrobiese middels is gedurende $72 \%$ van die besoeke voorgeskryf. Die antimikrobiese middels wat die meeste voorgeskryf is, was die penisilliene (38.17\%), sulfoonamiede (22.49\%), tetrasikliene (9.34\%) en antiprotosoale middels (9.88\%). Die mees algemene diagnoses wat die voorskryf van antimikrobiese middels ingesluit het, was virale influenza, boonste lugweginfeksie, akute brongitis en pelviese inflammatoriese siekte. Die voorskryf van antibiotiese middels vir virale siektetoestande het op onoordeelkundige verbruik gedui omdat hierdie infeksies deur nie-bakteriële agente veroorsaak word en gevolglik selfbeperkend is. Antibiotika het dus geblyk onnodig en ontoepaslik te wees. Verdere navorsing in verband met standaard antimikrobiese behandelingsriglyne in private primêre gesondheidsorginrigtings in Suid-Afrika moet uitgevoer word.

\section{INTRODUCTION}

Antimicrobials can be regarded as the most commonly encountered class of drugs in prescriptions (Das, Roy, Kundu, Islam, Ram, Banerjee, Chaudhuri, Dutta \& Munshi, 2002:59) and this has led to their abuse globally. It has been reported that $20 \%$ to $50 \%$ of antibiotic prescriptions in community settings are believed to be unnecessary (Hooton \& Levy, 2001:1087). The semi-rational or irrational use of antimicrobials could be attributed to the use of multiple antimicrobials, nonuse of first choice antimicrobials on the basis of provisional diagnosis, and recourse to irrational and unnecessary antimicrobials (Das et al. 2002:59). Antimicrobials represent the most expensive therapeutic group among medications used in hospitals, and their use comes at a cost, not only of the medicine itself, but of side-effects and promoting ever-growing bacterial resistance to antibiotics (Kali \& Swingler, 2003:508). Antimicrobial resistance results in increased morbidity, mortality, and costs of health care (Shlaes, Gerding, John, Craig, Bornstein, Duncan, Eckman, Farrer, Greene, Lorian, Levy, McGowan, Paul, Ruskin, Tenover \& Watanakunakorn, 1997:584). As a group, antimicrobials contribute significantly to the cost of drugs and are claimed worldwide to account for $15 \%$ to $30 \%$ of the total health budget (Rehana, Nagarani \& Rehana, 1998:175). Increasing antibiotic resistance calls for optimal prescription of antimicrobial drugs in both inpatient and outpatient settings. The problem must be addressed by all sectors of the health care system, including patients, health care teams, payers, and the public health system (Dickerson, Mainous \& Carek, 2000:711). plied by a mixture of public and private health care providers. Private primary health care represents the first tier of the health care system for it provides basic-preventive and curative services (Uppal, Sarkar, Giriyappanavar \& Kacker, 1993:671).

It is not clear whether antimicrobials are used appropriately or not in the treatment of different disease states in this sector, therefore evaluations such as this is required at this level of the therapeutic chain, to ensure rational use of antimicrobials. The prescribing of antimicrobial agents has not yet been investigated in depth in the private primary health care setting in South Africa, despite the fact that these drugs account for the largest proportion of drug expenditures, particularly in developing countries (Kern, Rose, Hay, Muche, Frank \& Badenwürttemberg Interuniversity study group, 2001:127). It was therefore decided to investigate the prescribing patterns of antimicrobials, in a certain section of the private primary health care sector in South Africa. The results from this study will give an idea of antimicrobial prescribing in a certain section of the private primary health care setting in South Africa, and recommendations will be made, where possible, on how these agents can be used in a more rational and costeffective manner.

\section{METHODOLOGY}

Permission to conduct the study was granted by the private primary health care service provider and the North-West University Research and Human Ethics Committee.

Health services in the Republic of South Africa are sup- 


\section{Research design}

The specific objectives of the empirical study were to review, analyse and interpret the prescribing patterns of antimicrobials in order to assess the extent and pattern of use in the private primary health care sector in South Africa. The patterns of antimicrobial prescribing were determined after the drug had been dispensed. Thus, the research design was classified as a nonexperimental quantitative, retrospective drug utilisation study.

\section{Data source}

Data were obtained directly from the central database of a South African private primary health care group; therefore no direct manipulation of the data by the researcher was possible. It was assumed that all data obtained were correct and accurate. Nine private primary health care clinics ( $25 \%$ of the clinics) for which data were electronically available were randomly selected from 33 clinics situated in the different geographical areas of South Africa. Each clinic used the same documentation system (electronically) to document information of all consultations. It was assumed that all documentation on diagnoses and treatment had been recorded correctly. The study population consisted of 83655 patients who visited the nine clinics from 1 January to 31 December 2001.

\section{Classification systems used for antibiot- ics}

Antimicrobials were classified according to pharmacological groups as described in the Monthly Index of Medical Specialities (MIMS) (Snyman, 2004:252), and Anatomical Therapeutic Chemical (ATC) classifications (WHO, 2003), respectively. Antimicrobial prescribing patterns were analysed according to number of patients, consultations, age groups, gender and diagnoses. Only the overall costs of antimicrobials were analysed. All medicine items were prescribed according to generic names. The nine private primary health clinics used the same coding system to document the diagnosis made.

\section{The composition of the study population}

The study population was composed from the total patient population who received one or more antimicrobials for the period of 1 January to 31 December 2001. The criteria for inclusion in the study were: a valid patient record indicating the prescribing of one or more antimicrobial agents, and all the cases had to have a cost component. For the purposes of this study, antimicrobial agents are those drugs that are used for either prophylactic or therapeutic indications of bacterial infections, and the wrong indication is a major determinant of irrational antibiotic use.

\section{Data analysis}

Data were analysed by using the Statistical Analysis System (SAS Institute, 2000). Effect size (d-value) was used as descriptive statistic (Cohen, 1988:3). The effect sizes were utilised in determining whether there were practical significant differences between the average medicine costs. Ad-value of 0.8 or higher was assumed to have practical significance.

$d=(X a-X b) / S 1$

Where $\mathrm{Xa}=$ the average medicine treatment cost of $a$; $\mathrm{Xb}=$ the average medicine treatment cost of $b$; $\mathrm{S} 1=$ the maximum standard deviation between $a$ and $b$.

\section{Reliability and validity of the research in- struments}

The data for the study were obtained directly from the central database and thus no direct manipulation of the data by the researcher was possible. Data were obtained for a twelve-month period thus limiting external validity, implying that results can only be generalised to the specific database used, as well as to the specific study population.

\section{RESULTS}

\section{Gender distribution of patients}

The total number of patients that visited the nine clinics (Clinic A to Clinic I) from 1 January 2001 to 31 December 2001 was 83 655, of whom 59.50\% were females and $40.22 \%$ were males. Age was not indicated in $0.21 \%$ cases. The age distribution of patients is given in Table 1. 
Table 1: Age distribution of patients in the nine clinics $(n=83655)$

\begin{tabular}{|l|l|l|}
\hline AGE GROUP & NUMBER OF PATIENTS (n) & PERCENTAGE (\%) \\
\hline Birth to 1 month & 376 & 0.45 \\
\hline 2 months to 1 year & 3647 & 4.36 \\
\hline 2 to 6 years & 7086 & 8.47 \\
\hline 7 to 12 years & 4342 & 5.19 \\
\hline 13 to 20 years & 5914 & 7.07 \\
\hline 21 to 40 years & 36859 & 44.06 \\
\hline 41 to 60 years & 18613 & 22.25 \\
\hline 61 years and older & 6651 & 7.95 \\
\hline No age indicated & 177 & 0.21 \\
\hline TOTAL & 83655 & 100.00 \\
\hline
\end{tabular}

Table 2: Antimicrobial prescribing according to gender $(n=54658)$

\begin{tabular}{|l|l|l|}
\hline GENDER & NUMBER & PERCENTAGE (\%) \\
\hline Females & 33582 & 61.44 \\
\hline Males & 20939 & 38.31 \\
\hline No gender indicated & 137 & 0.25 \\
\hline TOTAL & 54658 & 100.00 \\
\hline
\end{tabular}

\section{Antimicrobials prescribed according to the total number of medicine items and consultations}

The total number of medicine items prescribed to the 83655 patients was 515976 at a total cost of R1716319. Of these, $18.69 \%$ (96 421) were antimicrobials costing R1 045108 (60.89\% of the total cost of all medication). The total number of consultations $(n=132585)$ in which antimicrobials were prescribed accounted for $72.72 \%$ $(n=96416)$ in all nine clinics.

\section{Antimicrobials prescribed according to pharmacological group and gender}

There were differences in the prescribing patterns of antimicrobials according to pharmacological group and gender. Female patients received the highest number of antimicrobial prescriptions accounting for $61.44 \%$ (n $=33582)$ and males received 38.31\% $(n=20939)$, in the nine clinics. Gender was not indicated in $0.25 \%$ (n
= 137) cases (Table 2 ). This could have been because there were more female patients than male patients that visited the clinics.

The most frequently prescribed antimicrobials according to pharmacological group in the nine clinics were penicillins, accounting for $38.17 \%$, followed by sulphonamides with $22.49 \%$, antiprotozoals (9.88\%) and tetracyclines (8.71\%) and other groups (20.87\%) (Table 3 ). Of the 23641 patients who received penicillins, females $(n=14157 ; 59.88 \%)$ received more than males $(n=9484 ; 40.12 \%)$. The average number of antimicrobials prescribed for each female patient who received antimicrobials varied between $1.18 \pm 0.48$ and $1.33 \pm$ 0.64 for that year. The average number of antimicrobials prescribed for males who received antimicrobials varied between $1.09 \pm 0.32$ and $1.95 \pm 0.46$. The statistical $d$ values calculated between the average numbers of antimicrobials prescribed per gender for the different clinics revealed that there was no difference of practical significance between the different clinics $(d<0.8)$. 
The maximum number of antimicrobials prescribed for females were 6 , and for males 5 for that year. The most commonly prescribed individual antimicrobials in the nine clinics were amoxycillin $250 \mathrm{mg}$, co-trimoxazole 480mg, and doxycycline 100mg.

\section{Antimicrobials prescribed according to age groups of patients}

In all nine clinics, the age groups 21 to 40 years, and 41 to 60 years, accounted for the highest number of patients (66.31\%; $n=55472)$ and the age group birth to one month for the lowest number of patients $(0.45 \%$; $n=376)$. There were differences in the prescribing patterns and cost of antimicrobials for the different age groups in the nine clinics. Patients in the age group 21 to 40 years received the highest number of antimicrobials, accounting for $47.11 \%(n=45420)$ of the total number of antimicrobials prescribed. This could be explained by the fact that people in these age groups represent the working and economically active class that could afford to visit the private primary health care clinics. The most frequently prescribed individual antimicrobials to patients in the age group 21 to 40 years were amoxycillin 250mg and co-trimoxazole 480mg (Table 4). This age group was diagnosed with the highest number of disease states (it was also the age group with the highest number of patients). The minimum costs of antimicrobials corresponded to those prescribed for patients in age groups one to six years, and seven to 12 years, and the maximum costs of antimicrobials corresponded to those prescribed for patients in the age groups 21 to 40 years, and 41 to 60 years. Significant practical differences in the cost of prescribed antimicrobials were observed when the age groups were compared ( $d>0.8$ ), for example lower costs for age groups one to six years, and seven to 12 years and the highest average costs for the age groups 21 years and older.

\section{Antimicrobials prescribed according to disease states}

Antimicrobials that were less often prescribed according to pharmacological group were cephalosporins, aminoglycosides and chloramphenicols. This variation in prescription patterns was influenced by the type of disease states presented by patients in the nine clinics. Most of the diagnoses ( $n=140723$ ) which were at the same time accompanied by antimicrobial prescriptions were related to respiratory tract infections. These were upper respiratory tract infection, viral influenza, acute bronchitis, common cold, cough and acute sinusitis (Table 4). There was a general trend in the nine clinics to prescribe antibiotics for all respiratory tract infections. This could indicate overuse and inappropriate use of antimicrobials in private primary health care settings, because many of these infections are caused by viruses or other nonbacterial agents, and are self-limiting. Therefore the use of antibiotic courses was neither necessary nor appropriate in these conditions.

\section{DISCUSSION}

The gender distribution of the patients who attended the nine clinics showed that there was female predominance in the clinics. According to Statistics South Africa (Census, 2001), there were more females than

Table 3: Most frequently prescribed antimicrobials according to pharmacological groups $(n=96421)$

\begin{tabular}{|l|l|l|l|}
\hline ANTIMICROBIAL GROUP & ATC* CLASIFICATION & NUMBER & PERCENTAGE (\%) \\
\hline Antiprotozoals & J01X & 9528 & $9.88 \%$ \\
\hline Penicillins & J01C & 36808 & $38.17 \%$ \\
\hline Sulphonamides & J01E & 21687 & $22.49 \%$ \\
\hline Tetracyclines & J01A & 8395 & $8.71 \%$ \\
\hline Other groups & & 20003 & $20.75 \%$ \\
\hline TOTAL & & 96421 & $100.00 \%$ \\
\hline
\end{tabular}

${ }^{*}$ ATC $=$ Anatomical Therapeutic Chemical 
Table 4: Antimicrobials most often prescribed for the different disease states presented in patients in the age group 21 to 40 years

\begin{tabular}{|l|l|l|}
\hline CLINIC & $\begin{array}{l}\text { DISEASE STATE MOST } \\
\text { OFTEN DIAGNOSED }\end{array}$ & $\begin{array}{l}\text { ANTIMICROBIAL MOST OFTEN } \\
\text { PRESCRIBED }\end{array}$ \\
\hline A & Viral influenza & Co-trimoxazole 480mg (J01EE01) \\
\hline B & Viral influenza & Amoxycillin 250mg (J01CA04) \\
\hline C & Acute bronchitis & Amoxycillin 250mg (J01CA04) \\
\hline D & Upper respiratory infection & Amoxycillin 250mg (J01CA04) \\
\hline E & Acute sinusitis & Amoxycillin 250mg (J01CA04) \\
\hline F & Viral influenza & Co-trimoxazole 480mg (J01EE01) \\
\hline G & Acute bronchitis & Amoxycillin 250mg (J01CA04) \\
\hline H & Acute bronchitis & Amoxycillin 250mg (J01CA04) \\
\hline I & Acute bronchitis & Amoxycillin 250mg (J01CA04) \\
\hline
\end{tabular}

males in South Africa in 2001 (53.70\% vs. 46.30\%) (Statistics South Africa: Census, 2001).

The results of this study showed that antimicrobials were prescribed to approximately $65 \%$ of all patients that visited the nine clinics in the one-year period. Antimicrobials accounted for $18.69 \%$ of the total number of medicine items prescribed in the nine clinics. Astudy done in India reported that antimicrobials accounted for over $50 \%$ of the value of drugs sold (Harmeet, Nagarani \& Muushumi, 1998:175).

The drugs most commonly sold in developing countries are antimicrobials (Calva, 1996:1121). Data suggest that $20 \%$ to $60 \%$ of antimicrobials are inappropriately used (Hooton \& Levy, 2001:1087). A study on antibiotic usage in Eastern Nepal, reported that the increasing overuse of these agents results in enormous hospital expenditure worldwide accounting for $15 \%$ to $30 \%$ of the total health budget (Rehana et al. 1998:175). Another study conducted in India reported that antimicrobials represented up to $50 \%$ of the drug budget and that policies that target the optimal usage of antiinfectives are likely to have an economic impact on health expenditure (Davey, Malek \& Parker, 1992:409).

The high percentage of consultations (72.72\%) obtained in this study, which included prescriptions for antimicrobials could be a result of physicians commonly prescribing antibiotics to meet patient expectations, even when antimicrobials are unnecessary. This state of affairs could indicate overuse of these agents in this section of private primary health care sector in South Africa.

Antimicrobials prescribed most frequently were penicillins (amoxycillin), sulphonamides (co-trimoxazole) and tetracyclines (doxycycline) in that order. This was influenced by the clinical diagnoses presented in the clinics. These results concur with those obtained in a study done in Mexico (Juava, 1996:1121).

There were differences in the prescribing patterns and cost of antimicrobials in the different gender groups. This was due to differences in their numbers and disease states presented in each gender. Female patients were prescribed more antimicrobials (61.44\%) than male patients (38.31\%). The most prevalent antimicrobial prescribed according to pharmacological group and gender was penicillin ( $n=23989,43.03 \%)$ of which females received 14363 (59.87\%) and males received 9626 (40.13\%). Since the gender distribution in the nine clinics was such that there were more females than males, inevitably females received the highest number of antimicrobials in comparison with males. There were no differences of practical significance between the average costs of antimicrobials prescribed according to gender in the nine clinics $(d<0.8)$.

Results of this study indicate that a large proportion of 
the patients treated in the nine private primary health clinics were patients with upper respiratory tract infections, acute bronchitis and viral influenza. This gave an idea of the prevalence of the most common infectious diseases present in the different geographical areas of South Africa. It has been documented that respiratory tract infections are among the most common reasons for a visit to a family physician and leading to an antibiotic prescription (Naidoo \& Wilson, 2004:200). Antimicrobial agents commonly used to treat viral respiratory tract infections neither shorten the course of acute illness nor prevent secondary bacterial infections. The excessive and inappropriate use of antibiotics in viral respiratory tract infections leads to antibiotic resistance among the respiratory tract pathogens and adds an unnecessary economic burden to the health care system (Ochoa, Eiros, Inglada, Vallano, Guerra \& Spanish group on antibiotic treatment, 2000:73).

In spite of the knowledge that upper respiratory tract infection, popularly known as common cold, is viral in origin, there is evidence that many patients presenting to their general practitioners receive antibiotics, regardless of efficacy (Wang, Einarson, Kellner \& Conly, 1999:155). Results obtained in this study suggest that antimicrobials were overused in the nine private primary health care settings in South Africa. The widespread use and potential overuse of antimicrobials for primarily viral upper respiratory infections carries particular significance, because not only is there little evidence to support their effectiveness as treatments, but the inappropriate use of antimicrobial agents creates an environment for the development of resistance, placing both populations and individual patients at risk (Mainous, Hueston, Davis \& Pearson, 2003:1910). Reducing the use of antimicrobial agents can decrease the spread of resistance.

There were differences in antimicrobial prescribing in the eight different age groups. Antimicrobial usage in the different age groups indicated that patients in the age group 21 to 40 years received the highest number ( $n=47.11 \%$ ) of antimicrobials due to the fact that they are the working and economically active class, therefore could afford to visit the private primary health clinics. Patients in the age group 41 to 60 years received $20.88 \%$, while $10.46 \%$ of antimicrobials were prescribed to patients in age group one to six years and $5.59 \%$ to age group 61 years and older.
The differences in the prescribing patterns of antimicrobials for the different age groups could be explained by the numbers represented in each age group (Table 1), type of disease states, as well as the differences in the locations in different geographical areas of the country. These results showed inappropriate use of antimicrobials in older people (61 years and older), more so than in the case of young adults (21 to 40 years). The immunity of older patients is generally poorer than that of younger adult patients (Delafuente, 2003:133). Therefore antimicrobial usage should have been more frequent in the older patients. The results also indicated a high proportion of pediatric patients presenting with upper respiratory symptoms receiving antibiotic treatment prescriptions.

One study conducted in 2004 in South Africa, concluded that antibiotics did not improve the clinical course of sinusitis in patients presenting to general practitioners and that initial treatment could be limited to symptomatic management (Naidoo \& Wilson, 2004:200). The present study indicated the use of amoxycillin in the treatment of sinusitis. The increasing problem of antibiotic-resistant $\mathrm{H}$. influenza and $\mathrm{S}$. pneumoniae has provided further support for avoiding inappropriate antibiotic use in the managing of sinusitis (Poole, 1999:383).

Respiratory tract infections could be considered a serious health problem, since inappropriate use of antimicrobials for the treatment of viral upper respiratory tract infections has contributed to the development of resistant microorganisms (Garau \& Dagan, 2003:1936). Effective treatment of these infections must combine several elements, namely identification and elimination of risk factors, knowledge of the pathogen most frequently associated with the infection, determination of the patterns of local antimicrobial resistance as well as awareness of the pharmacokinetics, pharmacodynamics, and cost of the selected antibiotic. Strategies to combat the growing problem of antibiotic resistance emphasise treatment only for illnesses in which antibiotic use has proved to be beneficial and prescription of drugs with the narrowest reasonable range of activity (Mincey \& Parkulo, 2001:369).

In summary, antibiotics can decrease patient morbidity due to infections and can act as life saving drugs as well. However, their high efficacy and relative lack of 
adverse effects have resulted in overuse in many situations, and increasing resistance to available drugs has become a worldwide problem (Monroe \& Polk, 2000:496).

\section{RECOMMENDATIONS}

The results of this study indicate that antimicrobials were commonly used in this sample of private primary health care settings in South Africa and that in certain cases antimicrobials were probably overused and inappropriately used. It is recommended, therefore, that physicians in private primary health care settings be familiar with the clinical situations in which they should provide antibiotics and those in which such drugs need not be prescribed. The social aspects of the illness have to be addressed. It should be explained to patients that antibacterial drugs are not effective in viral infections, and it should be emphasised that unnecessary antibiotics can be harmful in several ways. Standard treatment guidelines for the most common bacterial infections in primary health care settings are to be implemented, with recognition of the existence of the potential obstacles to rational antibiotic prescribing.

\section{LIMITATIONS}

The following limitations of the study were considered when evaluating the results and conclusions: There was no direct manipulation of the data by the researcher since the data for the analysis were obtained from the database of one private primary health care service provider, thus limiting external validity, implying that results can only be generalised to the specific database used, as well as to the specific study population. The patterns of antimicrobial utilisation were determined after the antimicrobials had been dispensed and therefore no interventional activities were possible. It was assumed that all physicians' diagnoses, drugs, cost and protocols on the database were correct and accurate. Seasonal variation in the prescribing of antimicrobials was not evaluated in this study.

\section{ACKNOWLEDGEMENTS}

The authors thank the managers of the private primary health care service provider for the data used in this study, and Mrs. Mèlanie Terblanche for assisting in proofreading the manuscript.

\section{REFERENCES}

CALVA, J 1996: Antibiotic use in a periurban community in Mexico: A household and drugstore survey. Social Science and Medicine, 42(8):1121-1128.

COHEN, J 1988: Statistical power analysis for the behavioral sciences; $2^{\text {nd }}$ edition. New York: Lawrence Erlbaum Associates.

DAS, AK; ROY, K; KUNDU, KK; DAS, N; ISLAM, CN; RAM, AK; BANERJEE, SN; CHAUDHURI, SB; DUTTA, S \& MUNSHI, S 2002: Study of rational utilization and cost analysis of antimicrobials in a government teaching hospital. Indian Journal of Pharmacology, 34:59-61.

DAVEY, PG; MALEK, MM \& PARKER, SE 1992: Pharmacoeconomics of antibacterial treatment. Pharmacoeconomics, 1:409-36.

DELAFUENTE, JC 2003: Understanding and preventing drug interactions in elderly patients. Critical Reviews in Oncology/Hematology, 48:133-143.

DICKERSON, LM; MAINOUS, AG \& CAREK, PJ 2000: The pharmacist's role in promoting optimal antimicrobial use. Pharmacotherapy, 20(6):711-723.

GARAU, J \& DAGAN, R 2003: Accurate diagnosis and appropriate treatment of acute bacterial rhinosinusitis: Minimizing bacterial resistance. Clinical Therapeutics, 23(6):1936-1951.

HARMEET, SR; NAGARANI, MA \& MUUSHUMI, R 1998: A study on the drug prescribing pattern and use of antimicrobial agents at a tertiary careteaching hospital in Eastern Nepal. Indian Journal of Pharmacology, 30:175-80.

HOOTON, TH \& LEVY, SB 2001: Antimicrobial resistance: A plan of action for community practice. American Family Physician, 63:1087-1096.

JUAVA, C 1996: Antibiotic use in a periurban community in Mexico: A household and drugstore survey. Social Science \& Medicine, 42:1121-1128.

KALI, GTJ \& SWINGLER, G 2003: Evidence for antibiotic use for sore throat and URTI in general practice. Community Medical Education, 21(9):508-510.

KERN, WV; ROSE, AD; HAY, B; MUCHE, R; FRANK, U \& BADENWÛRTTEMBERG INTERUNIVERSITY STUDY GROUP 2001: Clinical and epidemiological study: Antimicrobial expenditures and usage at four university hospitals. Infection, 29(3):127-137. MAINOUS III, AG; HUESTON, WJ; DAVIS, MP \& PEARSON, WS 2003: Trends in antimicrobial prescribing for bronchitis and upper respiratory infections among adults and children. American Journal of Public Health, 93(11):1910-1914.

MINCEY, BA \& PARKULO, MA 2001: Antibiotic prescribing practices in a teaching clinic. South African Medical Journal, 94(4):365-369.

MONROE, S \& POLK, R 2000: Antimicrobial use and bacterial resistance. Current Opinion in Microbiology, 3:496 -501. 
NAIDOO, KT \& WILSON, D 2004: Treatment of common respiratory infections: The antibiotic dilemma. Continuing Medical Education, 22(4):200-203.

OCHOA, C; EIROS, JM; INGLADA, L; VALLANO, A; GUERRA, L \& SPANISH STUDY GROUP ON ANTIBIOTIC TREATMENT 2000: Assessment of antibiotic prescription in acute respiratory infections in adults. Journal of Infection, 41(1):73-83.

POOLE, MD 1999: A focus on acute sinusitis in adults; changes in disease management. American Journal of Medicine, 106(5A):383-475.

REHANA, HS; NAGARANI, MA \& REHAN, M 1998: A study on the drug prescribing pattern and use of antimicrobial agents at a tertiary care teaching hospital in Eastern Nepal. Indian Journal of Pharmacology, 30:175-180.

SAS FOR WINDOWS 9.1 2005, SAS Institute Inc; STATISTICAL ANALYSIS SYSTEM: 2000-2003.

SHLAES, DM; GERDING, DN; JOHN, JF; CRAIG, WA; BORNSTEIN DL; DUNCAN, RA; ECKMAN, MR; FARRER, WE; GREENE, WH; LORIAN, V; LEVY, S; MCGOWAN, JE; PAUL, SM; RUSKIN, J; TENOVER, FC \& WATANAKUNAKORN, C 1997: Society for health care epidemiology of America and infectious diseases society of America joint committee on the prevention of antimicrobial resistance: Guidelines for the prevention of antimicrobial resistance in hospitals. Clinical Infectious Diseases, 25:584-99.

SNYMAN, JR 2004: Antimicrobials. (In: Synman, JR 2005: Mims ${ }^{\text {TM }}$ Medical Specialities, 44:251-306).

STATISTICS SOUTH AFRICA: CENSUS 2001: Adjusted population figures by province, population group, sex and age, with $95 \%$ confidence. http://www.statssa.gov.za/census2001/census/dialog/includes/statscouncil.htm. (Date accessed: 4 April 2004). UPPAL, R; SARKAR, U; GIRIYAPPANAVAR, C \& KACKER, V 1993: Antimicrobial drug use in primary health care. Journal of Clinical Epidemiology, 46(7):671-673.

WANG, EE; EINARSON, TR; KELLNER, JD \& CONLY, JM 1999: Antibiotic prescribing for Canadian preschool children: Evidence of overprescribing for viral respiratory infections. Clinical Infectious Diseases, 29:155-60.

WHO (World Health Organization) Collaborating Centre for Drug Statistics Methodology 2003: New ATC Codes and DDDs, 26-27 May. http://www.whocc.no/atcddd/indexdatabase/index.php. (Date accessed: 29/09/2003). 